\title{
UJI AKTIVITAS INOKULUM TEMPE DARI BAHAN LIMBAH KULIT PISANG TERHADAP MUTU TEMPE KEDELAI
}

\author{
[Activity Tests of Tempeh Innoculum as Waste Material of Banana Peel to Quality of Soybean \\ Tempeh]
}

\author{
Muhammad Triyono ${ }^{1)^{*}}$ Nazaruddin $^{2)}$ Wiharyani Werdiningsih' ${ }^{2)}$ \\ 1) AlumniTeknologi pangan dan Agroindustri, Universitas Mataram \\ 2) Staf Pengajar Teknologi Pangan dan Agroindustri, Universitas Mataram \\ *Email: Muhammad.Triyono123@gmail.com
}

Diterima 5 April 2017/ Disetujui 18 April 2017

\begin{abstract}
Banana pulp can be used as a substrate in the manufacture of tempeh inoculum. The aimed of this study was to determine the activity of the tempe inoculum from banana pulp to the quailty of chemical, organoleptic and microbiological soybean tempeh. The experimental design used in this study was completely randomized design (CRD) with one factor was the concentration of inoculum (LIPI inoculum and banana pulp inoculum) with different concentrations on each treatment. Parameters measured were moisture content, ash content, protein content, total fungi, misellium observations, and also favorite sightings include compactness misellium raw tempeh, aroma and texture. The results showed that LIPI inoculum concentrations of $0.2 \%$, Banana Peel (KP) $0.1 \% ; 0.2 \% ; 0.3 \%$; and $0.4 \%$ had no different effect on moisture content, protein content, and ash content, but significantly different effect on the misellium compactness, texture, and flavor. The use of $0.3 \%$ inoculum of banana pulp is the best treatment for the quality of soybean tempeh with misellium compactness, texture, and aroma which preferred by the panelists with a moisture content of $58.66 \%$, ash content of $0.73 \%$, and protein content 20,31\% according to SNI 01-3144-1992.
\end{abstract}

Key words: banana pulp, inoculum, soybean tempeh

\section{ABSTRAK}

Limbah kulit pisang dapat dijadikan sebagai substrat dalam pembuatan inokulum tempe. Penelitian ini bertujuan untuk mengetahui aktivitas inokulum bahan limbah kulit pisang terhadap mutu kimia, organoleptik dan mikrobiologi tempe kedelai. Rancangan percobaan yang digunakan dalam penelitian ini adalah Rancangan Acak Lengkap (RAL) dengan satu faktor yaitu konsentrasi inokulum (Inokulum Buatan LIPI dan inokulum limbah kulit pisang) dengan konsentrasi yang berbeda pada tiap perlakuan. Parameter yang diamati adalah kadar air, kadar abu, kadar protein, total jamur, pengamatan misellium, dan juga kesukaan penampakan tempe mentah meliputi kekompakan misellium, aroma dan tekstur. Hasil menunjukkan bahwa faktor konsentasi inokulum LIPI 0,2\%, Kulit Pisang (KP) 0,1\%, KP 0,2\%, KP 0,3\%, KP 0,4\% memberikan pengaruh tidak berbeda nyata terhadap kadar air, kadar protein, kadar abu, tetapi memberikan pengaruh berbeda nyata terhadap kesukaan kekompakan misellium, tekstur, dan aroma. Penggunaan inokulum kulit pisang dengan konsentrasi $0,3 \%$ merupakan perlakuan terbaik terhadap mutu tempe kedelai dengan kekompakan misellium, tekstur, dan aroma yang disukai oleh panelis dengan kadar air 58,66\%, kadar abu 0,73\%, dan kadar protein 20,31\% sesuai dengan SNI 01-3144-1992.

Kata kunci: inokulum, kulit pisang, tempe kedelai

\section{PENDAHULUAN}

Tempe merupakan produk olahan kedelai yang terbentuk oleh aktifitas kapang jenis Rhizopus $s p$ melalui proses fermentasi. Tempe dapat dibuat dari berbagai bahan, tetapi yang dikenal sebagai tempe oleh masyarakat pada umumnya ialah tempe yang terbuat dari kedelai dengan ciri-ciri diantaranya berwarna putih dan bertekstur kompak (Kasmidjo,1990). Pada dasarnya cara pembuatan tempe meliputi tahapan sortasi dan pembersihan biji, hidrasi atau fermentasi asam, penghilangan kulit, perebusan, penirisan, pendinginan, inokulasi dengan inokulum tempe, pengemasan, dan inkubasi (Rahayu, 1998). Kualitas tempe dipengaruhi oleh bahan baku, proses pengolahan dan jenis inokulum yang digunakan (Nurahman, 2012). Inokulum merupakan bahan yang mengandung biakan jamur Rhizopus $s p$ yang berperan dalam proses fermentasi tempe. Bahan ini digunakan sebagai agensia pengubah kedelai rebus menjadi tempe, 
melalui proses fermentasi yang menyebabkan kedelai berubah karakteristiknya menjadi tempe (Kasmidjo, 1990). Penggunaan inokulum dalam memfermentasi tempe tidak terlepas dari konsentrasi inokulum yang digunakan, Konsentrasi inokulum tempe berbentuk bubuk dalam pembutan tempeyaitu sekitar 2-3 g untuk tiap 1 kgkedelai atau $0,2 \%$, karena kemampuan optimal inokulum memfermentasi tempe didapatkan pada konsentrasi 0,2\% (Sarwono, 2002). Berdasarkan penelitian Lusiawati (2012) penggunaan konsentrasi inokulum LIPI 0,3\% pada 100 gram kedelai menghasilkan tempe dengan tekstur dan kepadatan yang sangat kompak.

Dalam inokulum jenis kapang yang berperan dalam pembuatan tempe ialah Rhizopus oligosporus dan Rhizopus oryzae serta kapang lain seperti Rhizopusstolonifer dan Rhizopusarrhizus(Hidayat, 2009). Inokulum tempe yang telah dikenal masyarakat saat ini adalah usar dan inokulum bubuk produksi LIPI. Usar mengandung bakteri kontaminan yang cukup tinggi karena pada proses pembuatannya kurang memperhatikan kondisi aseptis. Jenis kapang yang terkandung pada usar juga bervariasi seperti Rhizopus $s p$ dan mikroganisme lain sehingga dapat menurunkan kualitas dari tempe kedelai (Sukardi,2008).

Inokulum LIPI penggunaannya lebih mudah dibandingkan dengan inokulumusar, selain itu tempe yang dihasilkan lebih stabil dan mengandung bakteri kontaminan dengan jumlah yang lebih rendah. Akan tetapi inokulum buatan LIPI ketersediaannya masih hanya sebatas memenuhi kebutuhan pasar daerah Jawa khususnya Bandung. Dengan demikian, untuk memenuhi kebutuhan pengrajin di daerah lain seperti NTB dan sekitarnya masih sangat kurang. Hal tersebut yang mendorong pengrajin tempe di NTBmasih banyak menggunakan inokulum usar.

Sebagai upaya untuk menyediakan inokulum tempe yang mudah didapat, beberapa penelitian terkait pembuatan inokulum tempe telah dilakukan, salah satunya dengan menggunakan limbah dari proses produksi pangan yaitu limbah ubi kayu bagian ujung dan lumbah kulit pisang. Menurut Widjastuti dan Hernawan (2012) kulit pisang mengandung karbohidrat, protein, serat kasar, lemak, kalsium dan fosfor. Kulit pisang mengandung karbohidrat yang cukup tinggi yaitu $18,50 \mathrm{~g}$ per $100 \mathrm{gram}$. Salah satu syarat
ISSN online: 2443-3446

utama suatu bahan atau substrat dapat menumbuhkan mikroorganisme kapang dengan baik ialah adanya kandungan karbohidrat yang digunakan sebagai sumber karbon pada substrat tersebut. Oleh karena itu, dilakukan penelitian pembuatan inokulum tempe dari kulit pisang.

\section{Bahan}

\section{BAHAN DAN METODE}

Bahan utama yang digunakan dalam penelitian ini adalah inokulum tempe dari kulit pisang kepok, inokulum merk RAPRIMA, dan Biji kedelai yang diperoleh dari pasar Kebon Roek, Ampenan. Bahan yang digunakan sebagai kemasan yaitu Plastik. Bahan yang digunakan untuk analisis yaitu medium Potato Dextrose Agar (PDA) merk poliform, larutan buffer phosphate, aquades, $\mathrm{NaOH} 0,1 \mathrm{~N}$, indikator merah metal, $\mathrm{H}_{2} \mathrm{SO}_{4}$, Kertas lakmus merah, $\mathrm{HCL}$, Bubuk Zn.

Alat

Alat-alat yang digunakan dalam penelitian ini adalahgelas ukur, pipet volume, pipet tetes, erlenmeyer, Labu Kjeldahl, baskom, timbangan analitik, pipet tetes, laminar flow, tabung reaksi, rak tabung, cawan petri, lampu bunsen, pipet mikro, blue tip, yellow tip, inkubator, drigalsky, hot plate, vortex, kapas, botol, colony counter, cetakan tempe, alat titrasi, kalkulator, kertas label, sarung tangan, oven, desikator, mortar, alat tulis, sendok dan piring, ayakan 100 mesh.

\section{Metode}

Metode yang digunakan pada penelitian ini adalah metode eksprimental menggunakan Rancangan Acak Lengkap (RAL) dengan percobaan faktorial satu faktor yaitu konsentrasi inokulum (A) yang terdiri dari 5 perlakuan yaitu A1 (inokulum LIPI 0,2\%); $A 2$ (KP 0,1\%); A3 (KP 0,2\%); A4 (0,3\%) dan A5 (KP 0,4\%). Masing masing diulang sebanyak 3 kali sehingga diperoleh 15 unit percobaan.

Proses pembuatan inokulum tempe kulit pisang terdiri dari persiapan bahan, pengukusan, pendinginan, pengecilan ukuran, inokulasi, inkubasi, pengeringan,dan pengayakan. Proses pembuatan tempe terdiri dari persiapan sampelsortasi, pencucian I, perebusan I, pencucian II, perendaman, pengupasan kulit ari, pencucian III, perebusan II, penirisan dan pendinginan, peragian, pembungkusan, fermentasi.

Data dari hasil pengamatan kimia dan organoleptik dianalisis menggunakan analisis 
keragaman (Analysis of Variance) pada taraf nyata $5 \%$ dengan menggunakan software CoStat. Jika terjadi perbedaan yang nyata hasil pengamatan kimia dan organoleptik akan dilakukan uji lanjut menggunakan uji Beda Nyata Jujur (BNJ) (Hanafiah, 2002). Adapun pada pengamatan hasil uji mikrobiologi menggunakan metode Deskriptif .

\section{HASIL DAN PEMBAHASAN}

\section{Mutu Mikrobiologi \\ Total Jamur}

Hasil pengamatan jenis dan konsentrasi inokulum dapat dilihat pada Tabel 1.

Tabel 1. Hasil Pengamatan Total Pertumbuhan Jamur Tempe Kedelai

\begin{tabular}{cc}
\hline $\begin{array}{c}\text { Konsentrasi } \\
\text { Inokulum (\%) }\end{array}$ & $\begin{array}{c}\text { Rerata Total Jamur } \\
\text { (CFU/gram) }\end{array}$ \\
\hline LIPI 0,2 & $<1,0 \times 10^{2}$ \\
KP 0,1 & $<1,0 \times 10^{2}$ \\
KP 0,2 & $<1,0 \times 10^{2}$ \\
KP 0,3 & $<1,0 \times 10^{2}$ \\
KP 0,4 & $<1,0 \times 10^{2}$ \\
\hline
\end{tabular}

Berdasarkan Tabel 1 terlihat bahwa purata total jamur pada tempe kedelai dengan perlakuan jenis inokulum LIPI $0,2 \%$ dan jenis inokulum kulit pisang pada semua konsentrasi adalah $<1,0 \times 10^{2} \mathrm{CFU} / \mathrm{gram}$. Hasil tersebut menunjukkan pertumbuhan jamur dari inokulum LIPI dan inokulum kulit pisang pada semua perlakuan mempunyai kemampuan aktivitas yang sama. Hal ini disebabkan karena kedua jenis inokulum mengandung Rhizopus oligosporus yang mampu tumbuh pada substrat yang mengandung karbohidrat berupa gula, pati dan serat.

Tingginya pertumbuhan jamur pada tempe kedelai disebabkan pada kedua inokulum mempunyai kemampuan tumbuh pada substrat kedelai dan juga konsentrasi inokulum yang digunakan dengan jumlah yang sesuai dengan kebutuhan kedeleai sehingga jamur dapat tumbuh secara optimal. Selain itu, kondisi ruang fermentasi juga sangat mempengaruhi pertumbuhan jamur pada tempe. Suhu ruang yang dipakai pada saat fermentasi tempe kedelai yaitu berkisar antara $33-39^{\circ} \mathrm{C}$ dan kelembaban relatif atau $\mathrm{RH}$ berkisar 55-69\%. Hal ini sesuai dengan pernyataan Madigan (2012) yang menyatakan bahwa Rhizopus oligosporus dapat tumbuh optimum pada suhu $30-35^{\circ} \mathrm{C}$, dengan suhu minimum $12^{\circ} \mathrm{C}$, dan suhu maksimum $42^{\circ} \mathrm{C}$, dan dengan $\mathrm{RH}$ antara $62-85 \%$.

\section{Pengamatan Miselium}

ISSN online: 2443-3446

Pertumbuhan misellium tempe dapat dilihat pada Tabel 2 .

Tabel 2. Hasil Pengamatan Misellium Tempe Kedelai

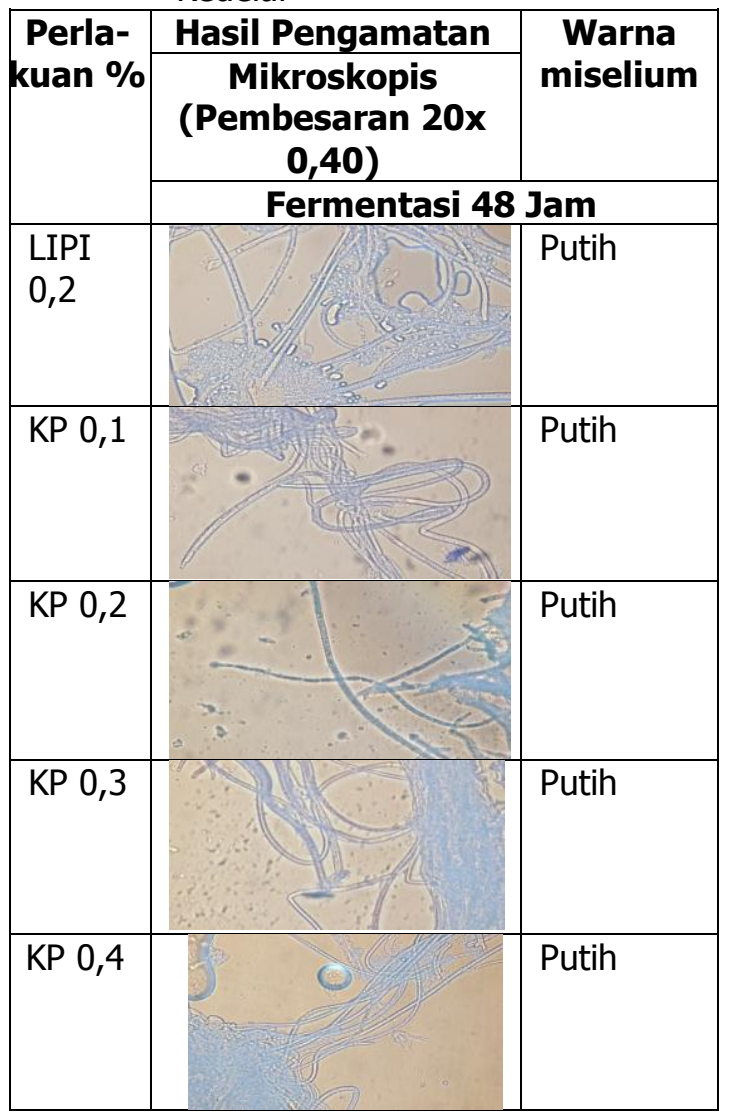

Berdasarkan Tabel 2 terlihat banyaknya pertumbuhan misellium untuk semua perlakuan. Terdapat kesamaan ciri misselium jamur inokulum LIPI dan jenis inokulum kulit pisang. Hal ini disebabkan oleh substrat yang dimanfaatkan oleh jamur untuk tumbuh dari kedua jenis inokulum yang sama yaitu karbohidrat yang dijadikan sumber karbon. Pada inokulum LIPI, substrat yang digunakan yaitu karbohidrat yang berasal dari nasi sedangkan jenis inokulum KP substrat yang digunakan yaitu kulit pisang sebagai sumber karbohidrat. Karbon pada karbohidrat digunakan jamur untuk tumbuh dan berkembang sehingga terbentuk hifa-hifa benang yang disebut misellium.

Berdasarkan hasil pengamatan, lama waktu fermentasi 48 jam menghasilkan misellium yang lebih banyak. Tingginya laju pertumbuhan misellium diduga karena fermentasi 48 jam merupakan waktu optimum pertumbuhan jamur tempe yang yang membuat biakan jamur tempe tumbuh lebih banyak serta menghasilkan misellium yang banyak pula. Hal ini sesuai dengan pernyataan 
Kasmidjo (1990) yang menyatakan bahwa waktu fermentasi selama 30-50 jam merupakan fase optimal pertumbuhan jamur tempe. Selama fase ini, terjadi penurunan suhu, jumlah asam lemak yang dibebaskan dan pertumbuhan kapang hampir tetap atau bertambah dalam jumlah kecil, flavor spesifik tempe optimal, serta tekstur lebih kompak karena terbentuknya misellium pada tempe.

\section{Mutu Kimia}

\section{Kadar Air}

Jenis dan konsentrasi inokulum memberikan hasil tidak berbeda nyata pada semua perlakuan (Gambar 1).

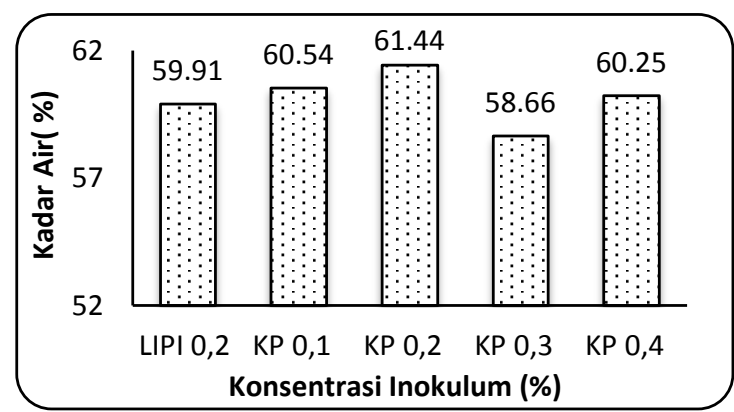

Gambar 1. Grafik Pengaruh Jenis dan Konsentrasi Inokulum terhadap Kadar Air Tempe

Tidak adanya perbedaan kadar air dikarenakan kedua jamur yang terdapat pada jenis inokulum LIPI dan jenis inokulum kulit pisang mempunyai aktivitas pertumbuhan yang sama sehingga proses metabolisme (glikolisis) oleh jamur dapat menghasilkan uap air sehingga dari semua perlakuan tidak menunjukan pengaruh yang berbeda.

Menurut Rochmah (2008) selama fermentasi tempe akan mengalami perubahan dan perombakan senyawa yang terdapat pada kedelai melalui proses glikolis. Glikolisis ialah proses perombakan senyawa karbohidrat (gula kompleks) menjadi senyawa yang lebih sederhana dan menghasilkan energi. Dalam fermentasi proses glikolisis terjadi melalui mikrobia mencerna substrat karbohidrat dan menghasilkan air, karbondioksida dan sejumlah besar energi (ATP).

Berdasarkan Gambar 1terlihat bahwa kisaran kadar air dari semua perlakuan adalah 58,66\%-61,66\%. Menurut SNI 01-3144-1992 menyebutkan bahwa kadar air maksimal pada tempe yaitu $65 \%$, sehingga tempe kedelai yang dihasilkan memenuhi syarat mutu kadar air.

\section{Kadar Protein}

ISSN online: 2443-3446

Jenis dan konsentrasi inokulum tidak memberikan pengaruh yang berbeda nyata terhadap kadar protein tempe kedelai (Gambar 2).

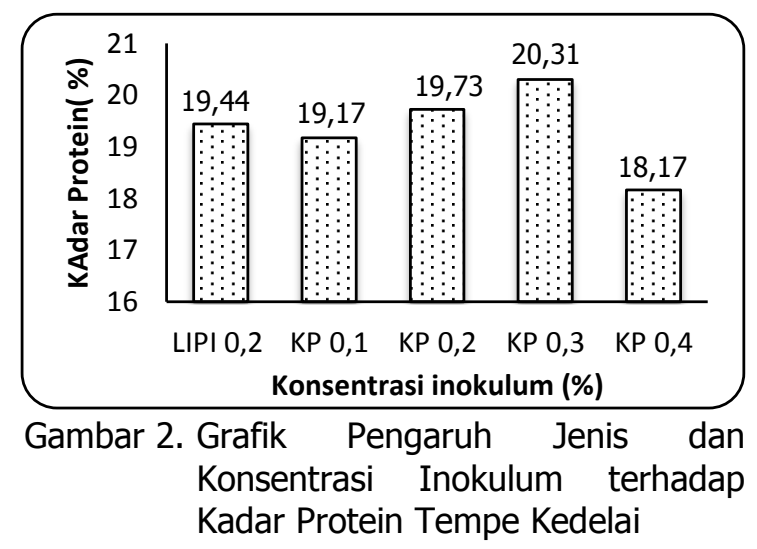

Tidak adanya perbedaan kadar protein tempe pada jenis dan konsentrasi inokulum dikarenakan kedua jenis inokulum memiliki aktivitas pertumbuhan jamur yang sama, sehingga mengakibatkan proses metabolisme jamur sama antara kedua jenis inokulum. Pada proses metabolisme jamur menghasilkan enzim protease yaitu enzim yang mengurai senyawa gizi komplek salah satunya protein dari kedelai menjadi senyawa sederhana yaitu asam amino. Hal ini sesuai dengan pendapat Pangastuti (1996) bahwa jamur yang tumbuh pada kedelai menghasilkan enzim-enzim pemecah senyawa-senyawa kompleks. $R$. oligosporus menghasilkan enzim-enzim protease. Perombakan senyawa kompleks protein menjadi senyawa-senyawa lebih sederhana yaitu asam amino adalah penting dalam fermentasi tempe, dan merupakan salah satu faktor utama penentu kualitas tempe, yaitu sebagai sumber protein nabati yang memiliki nilai cerna tinggi karena lebih mudah untuk diserap dan dimanfaat oleh tubuh secara langsung.

Berdasarkan Gambar 2 terlihat bahwa kisaran kadar protein dari semua perlakuan adalah 18,17\%-20,31\%. Menurut SNI, persyaratan untuk kadar protein tempe minimal $16 \%$. Adapun kadar protein tertinggi tempe kedelai dari hasil adalah 20,31\%. Menurut hasil tersebut, kadar protein tempe kedelai dengan penggunaan inokulum kulit pisang memenuhi syarat mutu SNI tempe.

\section{Kadar Abu}

Jenis dan konsentrasi inokulum LIPI tidak memberikan pengaruh terhadap kadar abu tempe kedelai (Gambar 3). Hal ini 
dikarena kedua jenis inokulum memiliki aktivitas pertumbuhan jamur yang sama, mengakibatkan proses metabolisme jamur sama antara kedua jenis inokulum, sehingga tingkat dan kadar abu yang dihasilkan memiliki nilai yang relatif sama dari kedua jenis inokulum LIPI maupun kulit pisang.

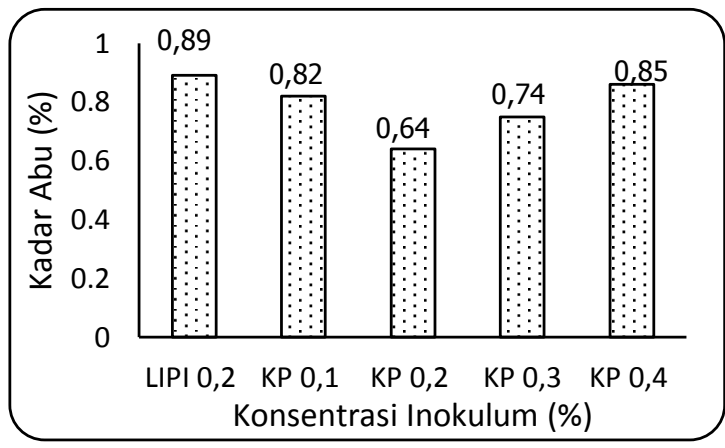

Gambar 3. Grafik Pengaruh Jenis dan Konsentrasi Inokulum terhadap Kadar Abu Tempe Kedelai

Faktor lain yang mempengaruhi kadar abu adalah mineral yang ada pada bahan baku. Pada penelitian ini, bahan baku yang digunakan adalah kedelai dengan jumlah yang sama sehingga kandungan mineral yang terkandung pada tempe relatif sama.

Berdasarkan Gambar 3 terlihat bahwa kisaran kadar abu dari semua perlakuan adalah $0,64 \%-0,89 \%$. Menurut SNI tahun (2009) menyebutkan bahwa kadar abu pada tempe maksimal $1,5 \%$, sehingga kadar abu tempe kedelai yang dihasilkan telah memenuhi syarat mutu SNI tempe.

\section{Mutu Organoleptik Kekompakan Misellium}

Tingkat penerimaan panelis pada kekompakan misellium dapat dilihat pada Gambar 4.

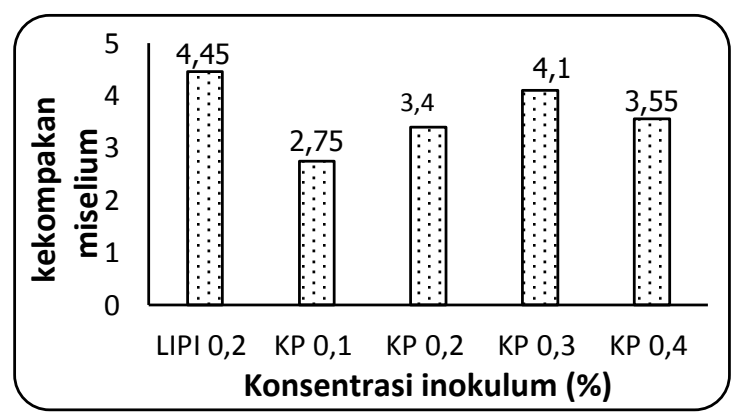

Gambar 4. Grafik Pengaruh Jenis dan Konsentrasi Inokulum terhadap Kesukaan Kekompakan Misellium Tempe Kedelai.
ISSN online: 2443-3446

Berdasarkan Gambar 4 terlihat bahwa nilai purata penilaian panelis terhadap kesukaan kekompakan misellium berkisar 2,75 sampai 4,50 dengan kriteria tidak suka sampai suka. Penggunaan inokulum LIPI $0,2 \%$; inokulum kulit pisang $0,3 \%$ dan $0,4 \%$ disukai panelis, inokulum kulit pisang $0,2 \%$ agak disukai panelis, dan inokulum kulit pisang $0,1 \%$ tidak disukai panelis. Tingkat kesukaan panelis terdapat pada penggunaan inokulum LIPI $0,2 \%$. Hal ini diduga karena misellium tempe pada perlakuan ini memiliki kekompakan yang sangat baik. Inokulum kulit pisang 0,3\% menujukkan tingkat kesukaan panelis terhadap kekompakan miselium yang tidak berbeda nyata dengan jenis inokulum LIPI $0,2 \%$. Hal ini menunjukkan aktivitas inokulum kulit pisang $0,3 \%$ aktivitasnya sangat baik dan menunjukan konsentrasi yang tepat untuk pembuatan tempe. Kekompakan misellium yang terbentuk diduga karena adanya aktivitas jamur $R$. oligosporus yang baik dan optimal sehingga dapat melakukan metabolisme yang optimal dan menghasilkan miselium tempe yang kompak.

Panelis memberikan respon tidak suka terhadap kekompakan misellium pada perlakuan jenis inokulum kulit pisang 0,1\% diduga karena misellium pada tempe ini kurang kompak sehingga panelis kurang meminati tempe pada perlakuan ini. Hal ini disebabkan karena konsentrasi inokulum yang digunakan adalah rendah sehingga pertumbuhan jamur kurang optimal untuk memfermentasi kedelai. Kurang optimalnya pertumbuhan jamur akan berdampak pada kurangnya misellium yang tumbuh. Hal ini sesuai dengan pernyataan Karsono (2008), bahwa faktor yang berpengaruh pada pertumbuhan misellium kapang tergantung pada konsentrasi inokulum sebagai substrat pertumbuhan kapang.

\section{Kesukaan Aroma}

Tingkat penerimaan panelis pada aroma tempe bisa dilihat pada Gambar 5 . Berdasarkan Gambar 5 terlihat bahwa nilai rerata penilaian panelis terhadap kesukaan aroma yang diuji secara hedonik berkisar 2,854,35 dengan kriteria tidak suka, agak suka, dan suka. Penggunaan jenis inokulum LIPI $0,2 \%$ dan inokulum kulit pisang $0,3 \%$ memiliki kriteria aroma yang disukai, inokulum kulit pisang $0,2 \%$ agak disukai dan inokulum kulit pisang $0,1 \%$ dan $0,4 \%$ tidak disukai panelis. 


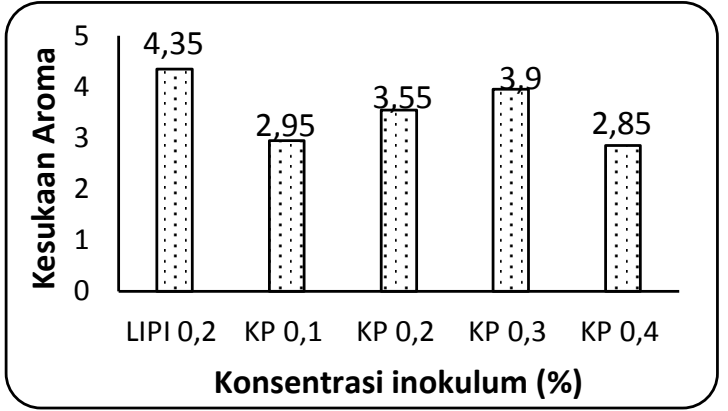

Gambar 5. Grafik Pengaruh Jenis dan Konsentrasi Inokulum terhadap Kesukaan Aroma Tempe Kedelai.

Tingkat kesukaan panelis terhadap aroma tempe ditemukan pada inokulum LIPI $0,2 \%$. Hal ini diduga karena aroma tempe pada perlakuan ini beraroma normal (khas tempe) karena substrat pertumbuhan inokulum LIPI berasal dari nasi yang memiliki aroma yang netral, sehingga lebih disukai panelis dibandingkan aroma tempe kedelai pada perlakuan lainnya yang substrat pertumbuhan inokulumnya berasal dari kulit pisang yang memiliki aroma yang tidak familiar dengan panelis. Perlakuan konsentrasi inokulum kulit pisang 0,3\% menunjukkan nilai kesukaan aroma yang lebih tinggi dibandingakan perlakuan KP 0,1\%; 0,2\%; dan $0,4 \%$ karena konsentrasi $0,3 \%$ merupakan konsentrasi inokulum yang memiliki pertumbuhan misellium yang kompak yang tidak berbeda nyata dengan perlakuan konsentrasi inokulum LIPI $0,2 \%$, sehingga proses fermentasi dapat berjalan optimal dan menunjukkan nilai kesukaan dari panelis yaitu 3,90 hampir mendekati nilai kesukaan panelis terhadap kontrol konsentrasi inokulum LIPI $0,2 \%$. Hal ini menunjukan aktivitas konsentrasi inokulum kulit pisang 0,3\% yang baik dan tepat yang mampu melakukan proses metabolisme dengan sempurna saat fermentasi dan menghasilkan aroma khas tempe.

Ketidaksukaan panelis pada aroma tempe dengan perlakuan konsentrasi inokulum kulit pisang $0,1 \%$ diduga karena aroma tempe kedelai pada perlakuan tersebut kurang beraroma tempe karena pertumbuhan jamur $R$. oligosporus yang tidak kompak sehingga fermentasi kurang optimal dan adanya aroma kulit pisang pada tempe, sehingga kurang diminati oleh panelis. Sedangkan pada konsentrasi kulit pisang 0,4\% pertumbuhan jamur kurang optimal dikarena konsentrasi inokulum yang terlalu tinggi dari kebutuhan sampel sehingga proses fermentasi berjalan terlalu cepat dan tempe menjadi terlalu matang dan aroma khas tempe tidak dapat dihasilkan karena tempe sudah kelewat matang. Proses fermentasi tidak lagi membentuk tempe akan tetapi membentuk hasil fermentasi sekunder serta tersier sehingga flavor yang dihasilkan cenderung tidak disukai panelis.

\section{Kesukaan Tekstur}

Tingkat penerimaan panelis pada tekstur tempe dapat dilihat pada Gambar 6 .

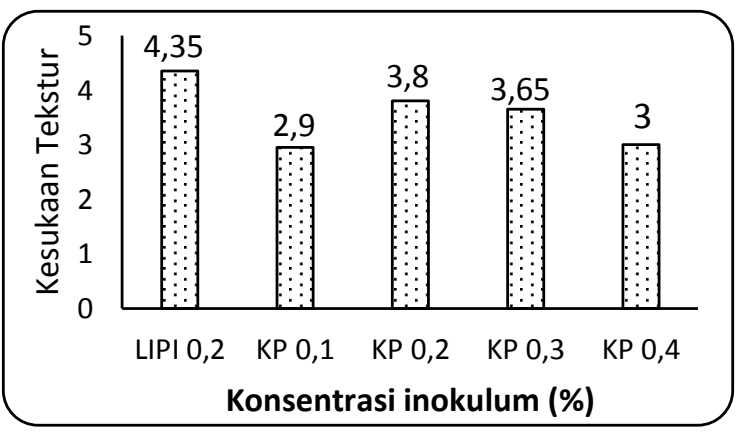

Gambar 6. Grafik Pengaruh Jenis dan Konsentrasi Inokulum terhadap Kesukaan Tekstur Tempe Kedelai

Berdasarkan Gambar 6 terlihat bahwa nilai rerata penilaian panelis terhadap kesukaan tekstur yang diuji secara hedonik adalah 2,95-4,35 dengan kriteria tidak suka sampai suka. Tekstur tempe yang disukai panelis adalah pada penggunaan inokulum LIPI $0,2 \%$, inokulum kulit pisang $0,2 \%$ dan $0,3 \%$. Tekstur tempe yang agak disukai ditemukan pada tempe dengan inokulum kulit pisang $0,4 \%$. Adapun tekstur tempe yang tidak disukai ditemukan pada inokulum kulit pisang $0,1 \%$.

Daya terima panelis untuk kesukaan tekstur tempe tertinggi yaitu pada perlakuan konsentrasi inokulum LIPI 0,2\%. Hal ini diduga karena tekstur tempe kedelai pada perlakuan ini bertekstur padat sehingga lebih disukai. Padatnya tekstur tempe kedelai pada perlakuan ini diduga disebabkan oleh pertumbuhan misellium tumbuh menyebar dan merata pada permukaan biji dan membentuk suatu jaringan yang padat sehingga terjadi pengikatan yang kompak diantara biji. Hal ini sesuai dengan pernyataan Karsono (2008) yang menyatakan bahwa tekstur tempe yang baik yaitu tekstur tempe yang terikat padat dan tidak mudah hancur apabila dipegang dan diremas. 
Tingkat kesukaan tempe dengan inokulum kulit pisang 0,2\% tidak berbeda nyata dengan inokulum kulit pisang $0,3 \%$. Hal ini dikarenakan tingkat kekompakan misellium pada kedua konsentrasi tersebut tinggi dan tidak berbeda nyata dengan tingkat kekompakan missellium inokulum LIPI 0,2\%.

Ketidaksukaan panelis pada tempe dengan perlakuan konsentrasi inokulum kulit pisang $0,4 \%$ diduga karena tekstur tempe kedelai pada perlakuan ini berbentuk lembek sehingga kurang diminati panelis. Tektur lembek pada tempe ini diduga terjadi karena konsentrasi inokulum yang terlalu tinggi sehingga mengakibatkan pertumbuhan jamur yang lebih banyak dan mengakibatkan proses fermentasi dan daur hidup terlalu cepat sehingga tempe yang dihasilkan menjadi cepat busuk dan teksturmya semakin cepat lunak.

Adapun pada penggunaan inokulum kulit pisang $0,1 \%$ memiliki kekompakan misellium yang kurang kompak, sehingga tempe memiliki tekstur yang agak lembek dikarenakan konsentrasi inokulum adalah kurang sehingga jamur tidak dapat tumbuh optimal. Hal ini sesuai dengan pernyataan Karsono (2008), bahwa kekompakan dari tempe yang dihasilkan sangat dipengaruhi oleh karakter pertumbuhan dari kultur dan kondisi optimal dari pertumbuhan kultur.

\section{KESIMPULAN}

Berdasarkan hasil analisis serta uraian pembahasan yang terbatas pada lingkup penelitian ini maka dapat disimpulkan sebagai berikut: aktivitas inokulum kulit pisang dengan konsentrasi $0,3 \%$ menunjukkan aktivitas yang sama/tidak berbeda nyata dengan inokulum LIPI 0,2\% dengan kekompakan miselium dan aroma yang disukai oleh panelis, kadar air 58,66\%; kadar protein 20,31\%; dan kadar abu $0,74 \%$. Tempe yang dihasilkan pada semua perlakuan telah memenuhi standar SNI 01-3144-1992 yaitu berturut-turut kadar air maksimal $65 \%$, kadar protein minimal $16 \%$, dan kadar abu maksimal 1,5\%.

\section{DAFTAR PUSTAKA}

Astuti M. 1996. Sejarah Perkembangan Tempe. dalam Sapuan dan Soetrisno N. Bunga Rampai Tempe Indonesia. Yayasan Tempe Indonesia, Jakarta.
ISSN online: 2443-3446

Fardiaz S. 1989. Mikrobiologi Pangan. PAU Pangan dan Gizi, Institut Pertanian Bogor, Bogor.

Fardiaz S. 1992. Petunjuk Laboratorium Mikrobiologi Pengolahan Pangan. Departemen Pendidikan dan Kebudayaan Direktorat Jenderal Pendidikan Tinggi. Pusat Antar Universitas Pangan dan Gizi Institut Pertanian Bogor, Bogor.

Karsono $Y$,Tunggal A, Wiratrama A, Adimulyo $P$. 2008. Pengaruh Jenis Kultur Starter terhadap Mutu Organoleptik Tempe Kedelai. www.repository.ipb.ac.id. Departemen Ilmu dan Teknologi Pangan, Institut Pertanian Bogor, Bogor.

Kasmidjo RB. 1990. Tempe Mikrobiologi dan Biokimia Pengolahan serta Pemanfaatannya. Pusat Antar Universitas Pangan dan Gizi UGM, Yokyakarta.

Madigan MT, Martinko JM, Stahl DA, dan ClarkDP. 2012. Brock Biology of Microorganism Global Edition Thirteenth Edition. Pearson Education Inc. San Frascisco.

Nurahman. 2012. Pertumbuhan jamur, sifat organoleptik dan aktivitas antioksidan tempe kedelai hitam yang diproduksi dengan berbagai jenis inokulum. Agritech, 32(1):60-65.

Rahayu WP. 1998. Penuntun Praktikum Penilaian Organoleptik. Fakultas Teknologi Pertanian, Institut Pertanian Bogor, Bogor.

Sarwono. 2004. Membuat Tempe dan Oncom. Penebar Swadaya, Jakarta.

SNI. 2009. Tempe Kedelai. BadanStandardisasi Nasional SNI 3144:2009. Jakarta.

Sukardi. 2008. Uji coba penanganan inokulum tempe dari kapang Rhizopus oryzae dengan substrat tepung beras dan ubi kayu pada unit produksi tempe sanan kodya malang. JTeknologi Pertanian, 9(3): 207-215.

Suprapti ML. 2003. Pembuatan Tempe. Kanisius. Yogyakarta. 